J Bioenerg Biomembr. 2017 February ; 49(1): 13-25. doi:10.1007/s10863-016-9652-1.

\title{
Physiological roles of the mitochondrial permeability transition pore
}

\author{
Nelli Mnatsakanyan ${ }^{1}$, Gisela Beutner ${ }^{2}$, George A. Porter ${ }^{2}$, Kambiz N. Alavian ${ }^{3}$, and \\ Elizabeth A. Jonas ${ }^{1}$ \\ ${ }^{1}$ Department Internal Medicine, Section of Endocrinology, Yale University, New Haven, CT, USA \\ ${ }^{2}$ Department of Pediatrics (Cardiology), University of Rochester Medical Center, Rochester, NY, \\ USA
}

${ }^{3}$ Division of Brain Sciences, Department of Medicine, Imperial College London, London, UK

\section{Abstract}

Neurons experience high metabolic demand during such processes as synaptic vesicle recycling, membrane potential maintenance and $\mathrm{Ca}^{2+}$ exchange/extrusion. The energy needs of these events are met in large part by mitochondrial production of ATP through the process of oxidative phosphorylation. The job of ATP production by the mitochondria is performed by the $\mathrm{F}_{1} \mathrm{~F}_{\mathrm{O}}$ ATP synthase, a multi-protein enzyme that contains a membrane-inserted portion, an extra-membranous enzymatic portion and an extensive regulatory complex. Although required for ATP production by mitochondria, recent findings have confirmed that the membrane-confined portion of the c-subunit of the ATP synthase also houses a large conductance uncoupling channel, the mitochondrial permeability transition pore (mPTP), the persistent opening of which produces osmotic dysregulation of the inner mitochondrial membrane, uncoupling of oxidative phosphorylation and cell death. Recent advances in understanding the molecular components of mPTP and its regulatory mechanisms have determined that decreased uncoupling occurs in states of enhanced mitochondrial efficiency; relative closure of mPTP therefore contributes to cellular functions as diverse as cardiac development and synaptic efficacy.

\section{Keywords}

Mitochondria; Permeability transition pore; Synaptic transmission; Synaptic plasticity; ATP synthase

\section{Calcium re-release from mitochondria after synaptic activity determines short term plasticity}

$\mathrm{Ca}^{2+}$ re-release from mitochondria determines short term synaptic plasticity in many neuronal synapses (Zucker \& Regehr, 2002). During neuronal activity, $\mathrm{Ca}^{2+}$ enters across the plasma membrane through glutamate receptors and voltage gated $\mathrm{Ca}^{2+}$ channels. $\mathrm{Ca}^{2+}$ 
clearance from the cytosol is performed by the actions of $\mathrm{Ca}^{2+}$ ATPases at the plasma membrane and by buffering through uptake by intracellular stores including the endoplasmic reticulum (ER) and mitochondria (Rizzuto et al., 2012; Lopreiato et al., 2014); these processes reset the normally low $\mathrm{Ca}^{2+}$ levels present in resting neurons or neuronal synapses. The $\mathrm{Ca}^{2+}$ that is buffered by mitochondria is rapidly re-released within the presynaptic cytosol, providing for residual $\mathrm{Ca}^{2+}$ within presynaptic endings. Residual $\mathrm{Ca}^{2+}$ increases total $\mathrm{Ca}^{2+}$ levels during subsequent neuronal activity, enhancing the amount of neurotransmitter released for a given stimulus (Neher \& Sakaba, 2008; Jonas, 2006) (Figs. 1 and 2). In squid presynaptic terminal, the high level of $\mathrm{Ca}^{2+}$ contained in sea water causes a marked synaptic depression which masks short term synaptic potentiation. Upon lowering extracellular $\mathrm{Ca}^{2+}$, short term potentiation after a tetanus reappears, and is dependent on synaptic mitochondria, as in other synapses (Jonas et al., 1999).

$\mathrm{Ca}^{2+}$ - sensitive ligand gated channels in mitochondrial membranes are widely conserved in species from invertebrates to mammals although in many cases their molecular identity and or $\mathrm{Ca}^{2+}$ binding domains is/are not known. These channels open in response to elevated $\mathrm{Ca}^{2+}$ within the mitochondrial matrix and comprise part of the machinery that maintains residual $\mathrm{Ca}^{2+}$ levels for enhanced presynaptic vesicle fusion. In the example of the squid presynaptic terminal, the opening of a $\mathrm{Ca}^{2+}$ - activated mitochondrial channel in response to neuronal activity enhances neurotransmitter release from presynaptic endings (Jonas et al., 1999; Jonas et al., 1997), consistent with a role for this channel in re-releasing mitochondrially-buffered $\mathrm{Ca}^{2+}$ within the presynaptic terminal after a phase of increased neuronal activity (Fig. 2). Electrophysiological recordings of mitochondrial membranes within the squid presynaptic terminal demonstrate that the conductance of mitochondrial membranes is low at rest (Jonas et al., 1999) but that mitochondrial membrane ion channel activity increases at about $1 \mathrm{~s}$ after the onset of neuronal activity and persists after neuronal activity has ended (Fig. 3a). Furthermore, mitochondrial activity and short term increases in post stimulation synaptic transmitter release are abrogated by applying the uncoupler FCCP (carbonyl cyanide $p$-trifluoromethoxyphenylhydrazone), which depolarizes mitochondria, preventing $\mathrm{Ca}^{2+}$ handling (Jonas et al., 1999; Tang \& Zucker, 1997; Friel \& Tsien, 1994) (Fig. 3b, c).

\section{Is the calcium sensitive channel of synaptic mitochondria the mitochondrial permeability transition pore (mPTP)?}

In order to begin to determine a molecular identity for the calcium release channel in presynaptic mitochondria, a comparison can be made to another known channel with $\mathrm{Ca}^{2+}$ sensitivity in the inner membrane, the mitochondrial permeability transition pore (mPTP). Permeability transition (PT) of the mitochondrial inner membrane has been extensively studied for its role in ischemic injury in brain, heart and other organs as well as in neurodegenerative conditions (10). In the heart, data suggest that opening of the mPTP during early reperfusion after ischemia is a harmful event that precipitates further damage to the myocardium (Griffiths \& Halestrap, 1995). However additional data also suggest that transient $\mathrm{mPTP}$ opening during preconditioning can be protective, thus serving a physiological role even during injury (Hausenloy et al., 2004). 
Another type of mitochondrial channel that also increases mitochondrial permeability is formed by proteins of the Bcl-2 family. Programmed cell death (apoptosis) in vertebrate cells may be initiated by signaling at the plasma membrane or by intracellular pathways that lead to changes in mitochondria (Kinnally et al., 2006). The final common pathway for programmed cell death in many systems is mitochondrial outer membrane permeabilization (MOMP) (Dejean et al., 2005; Dejean et al., 2006; Antonsson et al., 2000; Adams \& Cory, 2007), which is activated by formation of an outer membrane channel called MAC (Dejean et al., 2005; Dejean et al., 2006; Pavlov et al., 2001). Pro-apoptotic Bcl-2 family members such as Bax regulate MOMP by inducing the formation of large outer membrane pores comprised of activated oligomerized pro-apoptotic Bcl-2 proteins, aided by other proapoptotic moieties (Dejean et al., 2005; Antonsson et al., 2000; Kim et al., 2006). In their canonical role, the anti-apoptotic Bcl-2 family proteins such as Bcl- $\mathrm{x}_{\mathrm{L}}$ protect cells against MOMP by interacting with, and inhibiting the pore forming properties of the pro-apoptotic family members (Adams \& Cory, 2007; Kim et al., 2006; Galonek \& Hardwick, 2006).

MOMP leads to the release of several inter-membrane space proteins such as cytochrome $c$ (Green \& Kroemer, 2004; Martinez-Caballero et al., 2005). The resultant decrease in cytochrome $c$ levels compromises the ability of mitochondria to maintain the mitochondrial inner membrane potential and to produce ATP (Gottlieb et al., 2002). In addition, cytochrome $c$ released into the cytoplasm activates downstream cytosolic enzyme pathways including effector caspases that execute cell death (Youle \& Strasser, 2008). Whether the Bcl-2 proteins that regulate MOMP may also regulate MPTP activity and how these two activities are linked has been heretofore poorly understood. In addition, it is now well understood that caspase activity serves physiological roles (Li et al., 2010; Tang et al., 2015), raising the issue of whether MOMP, along with, or separate from, physiological opening of mPTP may occur reversibly.

\section{Physiological and metabolic role of the permeability transition pore}

To determine if mPTP may play a physiological role in $\mathrm{Ca}^{2+}$ buffering and re-release in presynaptic terminals, it is helpful to identity the pore region or channel of mPTP. This will enable studies to determine 1) if channel opening or PT occurs under physiological conditions and 2) how cellular processes regulate and are regulated by PT. To begin to narrow down the possible molecules that could form the pore, we considered the known regulators of $\mathrm{mPTP}$ in isolated mitochondria and in cells. Pathologically, mPTP opening is induced by elevated mitochondrial matrix $\mathrm{Ca}^{2+}$, ROS, inorganic phosphate, and intracellular acidification (Szabo et al., 1992; Giorgio et al., 2013). In contrast, PT is inhibited by ATP/ADP and $\mathrm{Mg}^{2+}$ (Kowaltowski et al., 1998; Crompton, 1999). Recent reports have also confirmed increased propensity toward PT caused by the presence of polyphosphates, chains of $10 \mathrm{~s}$ to $100 \mathrm{~s}$ of repeating phosphates linked by ATP-like high energy bonds (Abramov et al., 2007; Seidlmayer et al., 2012; Holmstrom et al., 2013; Stotz et al., 2014). The actions of $\mathrm{Ca}^{2+}$ may also require polyhydroxybutyrate (PHB), which enters mitochondria and enhances the ability of $\mathrm{Ca}^{2+}$ to induce PT (Elustondo et al., 2013). Although the above conditions occur under pathological circumstances, evidence for physiological opening of the mPTP has been described including flickering short of permanent opening (Hausenloy et al., 2004; Crompton, 1999; Huser \& Blatter, 1999; Korge et al., 2011; Petronilli et al., 1999; Wang et 
al., 2008; Ichas \& Mazat, 1998; Jouaville et al., 1998). An association between transient mPTP opening and "superoxide flashes" has been observed in striated muscle mitochondria (Wang et al., 2008). It has been hypothesized that transient opening of the MPTP may release mitochondrial matrix $\mathrm{Ca}^{2+}$ to maintain mitochondrial homeostasis (Elrod et al., 2010) although this function of the mPTP has recently been questioned (De Marchi et al., 2014). These studies provide a possible link between mPTP and a $\mathrm{Ca}^{2+}$ re-release channel that regulates physiological processes.

Metabolic pathways also regulate PT. Electron transport chain activity that increases mitochondrial membrane polarization inhibits PT, while membrane depolarization (a fall in membrane potential) enhances it (Haworth \& Hunter, 1979; Hunter \& Haworth, 1979; Di Lisa et al., 2011). Components of the glycolytic pathway may also control opening of the $\mathrm{mPTP}$, as the binding of hexokinase II to the OMM in cardiac myocytes inhibits MOMP and PT (Pasdois et al., 2013). Furthermore, a complex of ANT, VDAC, hexokinase, and mitochondrial creatine kinase (mtCK) regulates PT (Beutner et al., 1998; Beutner et al., 1996). These data suggest that mitochondrial electron transport, mitochondrial use of substrates and ADP/ATP (or creatine kinase) govern the opening of mPTP. Finally, major pharmacologic agents used to manipulate the MPTP also target metabolic pathways. For example, inhibitors of ANT can either attenuate (bongkrekic acid) or enhance (atractyloside) mPTP opening (Haworth \& Hunter, 1979). The pharmacological agent most efficient at inhibiting PT is cyclosporine A (CsA), an immunosuppressant drug which binds to cyclophilin D (CypD) and inhibits the channel activity associated with PT (Szabo \& Zoratti, 1991; Giorgio et al., 2009). CyPD binds to ANT, $F_{1} F_{O}$ ATP synthase, and the phosphate carrier, further suggesting a role for metabolic components in the regulation of mPTP (Giorgio et al., 2009).

\section{Electrophysiologic properties of the MPTP}

Combining the role of mPTP as a mitochondrial ion channel and as an entity involved intimately in cellular $\mathrm{Ca}^{2+}$ management and metabolic regulation provides clues to its molecular identity. We will first describe its biophysical features as a mitochondrial ion channel and will then describe its metabolic functions in neurons and heart with reference to possible roles in health and disease.

PT most likely begins as the opening of a $\mathrm{Ca}^{2+}$ sensitive ion channel in the inner mitochondrial membrane. Such a $\mathrm{Ca}^{2+}$ release channel is heavily regulated; therefore it is assumed that only after prolonged opening does pathological PT (followed by MOMP) occur (Bernardi, 1999). The conversion of a physiological $\mathrm{Ca}^{2+}$ extrusion mechanism into a pathological channel opening may be correlated with cellular energy failure and arrest of energy dependent $\mathrm{Ca}^{2+}$ extrusion mechanisms in the mitochondrion; nevertheless, the factors that regulate the transition from physiological to pathophysiological ion channel opening in the mitochondrion are not completely understood.

Description of the biophysical properties of the pore that opens in the inner mitochondrial membrane during PT (the mPTP) provide support for the notion that PT is initiated by the opening of an ion channel. The first patch clamp recordings of mitochondrial inner 
membrane were published in 1987 . This early report highlighted a $\sim 100 \mathrm{pS}$ channel recorded by patch-clamping giant mouse liver mitochondria produced by cuprizone application (Sorgato et al., 1987). In the late 1980s, a putative mPTP was recorded by patchclamping mitochondrial inner membrane or mitoplast preparations (Petronilli et al., 1989). The activity occurred at positive potentials of the patch pipette and was found either in whole organelle mode or in single channel recordings in the organelle-attached configuration. The activity was slightly anion over cation selective with multiple subconductance states ranging from $30 \mathrm{pS}$ to a peak single channel conductance of $1.3 \mathrm{nS}$. Lower conductances were attributed to substates of the larger channel openings because of long periods lacking activity followed by periods of multi-conductance behavior (Petronilli et al., 1989). Conductances of $550 \mathrm{pS}$ were frequently observed at positive potentials. Gating was less common at negative potentials but this observation was consistent with the presence of prolonged openings and fewer sub-conductance steps at negative patch potentials contrasted with increased flickering at positive potentials. The authors concluded that conductance levels were not sharply defined, consistent with the existence of many varied conductance levels of the channel.

Also in 1989, Kinnally et al. recorded a similar mitochondrial multiconductance channel (MMC) in mouse liver mitoplasts (Kinnally et al., 1989). This channel changed over time, with low activity at the onset of the recording followed by progressively higher activity at later times during the recording. The channels were sometimes open more frequently at negative potentials but at times rectification occurred in the opposite direction (more frequently open at positive potentials). Channel activity displayed multiple conductances ranging from 10 to $1000 \mathrm{pS}$ and was weakly cation-selective. These early studies began to establish expected criteria for activity of $\mathrm{mPTP}$.

Shortly after the first recordings of the putative MPTP were performed, similar inner membrane activity was found to be inhibited by CsA. In patch clamp experiments performed in liver mitochondria, channel activity was rapidly inhibited by submicromolar concentrations of CsA in a manner consistent with the expression of the binding site on the matrix side of the inner membrane. $\mathrm{Ca}^{2+}$ - activated large conductance channel activity up to $1.3 \mathrm{nS}$ was inhibitable, but a $107 \mathrm{pS}$ inner membrane conductance similar to the first recorded inner mitochondrial membrane channel was also observed in the recordings. This smaller conductance was resistant to CsA, suggesting that this activity might be due to a separate ion channel (Szabo \& Zoratti, 1991). The large conductance channel was sensitive to $\mathrm{Mg}^{2+}, \mathrm{Mn}^{2+}, \mathrm{Ba}^{2+}$ and $\mathrm{Sr}^{2+}$ in that order, which inhibited the activity in a competitive manner with $\mathrm{Ca}^{2+}$, the main activator of the channel (Szabo et al., 1992).

\section{Metabolic functions of the MPTP in cells: Characterization of a metabolic molecular complex surrounding the pore}

The recent identification of a molecular structure matching the biophysical properties of mPTP was aided by several reports showing that regulators of the pore bind to the ATP synthase. CypD, which had been known for many years to regulate PT, was found to bind to the stator arm of ATP synthase, specifically on the OSCP subunit (Giorgio et al., 2013; 
Giorgio et al., 2009). More recently we described that Bcl- $\mathrm{x}_{\mathrm{L}}$ enhances metabolic efficiency (decreases uncoupling) by binding to the $\beta$-subunit of the ATP synthase (Alavian et al., 2011; Chen et al., 2011). The third finding suggested that closure of the mPTP is related to the level of CypD activity in a developmentally regulated manner such that its activity falls at the onset of respiration in mammalian heart (Hom et al., 2011). This final report found that ATP synthase assembles into a very large complex with several proteins that may regulate the MPTP (Beutner et al., 2014). Since the first set of findings has been described in detail elsewhere, we will herein concentrate on the physiological and developmental regulation of an inner membrane uncoupling pore within the ATP synthase.

\section{Narrowing down the possibilities for mPTP structure: $\mathrm{Bcl}-\mathrm{x}_{\mathrm{L}}$ regulates metabolic efficiency by binding to the $\beta$-subunit of the ATP synthase}

Inefficiency of metabolism is correlated with cell death under conditions of neurodegeneration or acute cellular injury such as occurs during PT (Beal, 2007; Dodson \& Guo, 2007; Brand, 2005). In contrast, a highly efficient state of metabolism requires maximally decreased uncoupling of the inner membrane. In neurons as in other cells, calcium entry into mitochondria regulates ATP production and the efficiency by which calcium causes this effect may indeed be crucial to normal synaptic function (Chouhan et al., 2012). It has been found recently that Bcl-2 family proteins regulate efficiency of ATP production by binding directly to the ATP synthase (Alavian et al., 2011; Chen et al., 2011; Hockenbery et al., 1990). Although it was known previously that Bcl-2 family proteins regulate mitochondrial outer membrane permeability (Galonek \& Hardwick, 2006; Jonas, 2009), it now seems possible that $\mathrm{Bcl}-\mathrm{x}_{\mathrm{L}}$ forms part of a large protein complex that regulates mPTP and cell death at the inner mitochondrial membrane. This implies that it may fine tune metabolism in a physiological role in neurons.

During the initiation of cell death an important function of $\mathrm{Bcl}-\mathrm{x}_{\mathrm{L}}$, in addition to protection from MOMP, is to increase the release of ATP through enhanced VDAC opening (Gottlieb et al., 2002; Vander Heiden et al., 2000). This decreases the probability of MOMP in cancer cell lines by providing extra ATP to overcome cell death stimuli (Gottlieb et al., 2002; Vander Heiden et al., 2001). In the neuronal synapse, injection of either Bcl- $\mathrm{x}_{\mathrm{L}}$ or ATP enhances synaptic transmitter release (Jonas et al., 2003), suggesting that Bcl- $\mathrm{x}_{\mathrm{L}}$ increases ATP levels in the synapse (Hickman et al., 2008).

In support of a role for Bcl- $\mathrm{x}_{\mathrm{L}}$ in metabolic regulation in healthy cells, hippocampal neurons overexpressing Bcl- $\mathrm{x}_{\mathrm{L}}$ show a large increase in cytoplasmic ATP levels. Surprisingly, this increase in ATP accompanies a decrease in neuronal oxygen uptake and aerobic glycolysis, but an increase in synapse number, size and use (Li et al., 2008; Li et al., 2013) including an increase in mitochondrial targeting to synapses (Li et al., 2008; Berman et al., 2009) consistent with the notion that $\mathrm{Bcl}-\mathrm{x}_{\mathrm{L}}$ overexpression increases mitochondrial bioenergetic efficiency (Alavian et al., 2011; Chen et al., 2011). Bcl- $x_{L}$ depletion reverses these effects on metabolism, decreasing ATP production and increasing oxygen uptake by resting cells (Alavian et al., 2011; Chen et al., 2011). The regulation of inner membrane coupling by Bcl$\mathrm{x}_{\mathrm{L}}$ also may increase the efficiency of recovery of releasable vesicle pools in synapses that 
have undergone synaptic vesicle depletion. Studies show that inhibition of $\mathrm{Bcl}-\mathrm{x}_{\mathrm{L}}$ slows vesicle recovery to a $\mathrm{Ca}^{2+} /$ calmodulin dependent readily releasable pool but not to the reserve or recycling pools (Jonas et al., 2003; Hickman et al., 2008; Li et al., 2013), consistent with a role for mitochondria and/or Bcl- $\mathrm{x}_{\mathrm{L}}$ in vesicle docking at release-ready sites (Fig. 4).

\section{Regulatory molecules do not form the pore of mPTP}

We have found that $\mathrm{Bcl}-\mathrm{x}_{\mathrm{L}}$ regulates neuronal metabolism by interacting with the $\beta$-subunit of the ATP synthase (Alavian et al., 2011; Chen et al., 2011). A likely scenario is that Bcl- $\mathrm{x}_{\mathrm{L}}$ enhances the efficiency of ATP production by closing a leak or pore within the $\mathrm{F}_{1} \mathrm{~F}_{\mathrm{O}}$ ATP synthase itself; such a pore may also form mPTP. In support of this, $\mathrm{F}_{1} \mathrm{~F}_{\mathrm{O}}$ ATP synthase interacts with a large number of proteins many of which closely regulate mPTP such as ANT (Woodfield et al., 1998), CypD (Halestrap \& Davidson, 1990), VDAC (Crompton et al., 1998), hexokinase, mitochondrial creatine kinase (mtCK) (Beutner et al., 1998; Beutner et al., 1996) and PiC (Leung \& Halestrap, 2008), all of which have been touted as candidates for mPTP identity. Although genetic deletions of ANT1 and 2, PiC and VDAC demonstrate that these proteins are not essential to mPT pore formation, the studies still support regulatory roles for these molecules (Gutierrez-Aguilar et al., 2014; Kokoszka et al., 2004; Kwong et al., 2014; Gunter \& Sheu, 2009; Kinnally et al., 2011).

Evidence suggests that the regulatory molecules including $\mathrm{Bcl}-\mathrm{x}_{\mathrm{L}}$ form large macromolecular structures with $\mathrm{F}_{1} \mathrm{~F}_{\mathrm{O}}$ ATP synthase in the inner mitochondrial membrane. ANT and PiC form a complex with $\mathrm{F}_{1} \mathrm{~F}_{\mathrm{O}}$ ATP synthase called the synthasome (Chen et al., 2004). In addition, the large complex of ANT, VDAC, hexokinase and mtCK is likely also involved in the regulation of ATP synthesis (Beutner et al., 1998; Beutner et al., 1996). Therefore, each of these molecules may regulate the structure and activity of $F_{1} F_{O}$ ATP synthase, and, in so doing, modulate the opening of the mPTP.

\section{The c-subunit of $F_{1} F_{0}$ ATP synthase comprises the PT pore}

These various reports all agree that $\mathrm{F}_{1} \mathrm{~F}_{\mathrm{O}}$ ATP synthase is a major factor in the formation of the mPTP, and recent evidence suggests that the $F_{O}$ or membrane portion of $F_{1} F_{O}$ ATP synthase in fact forms the pore (Bonora et al., 2014; Bonora et al., 2013; Alavian et al., 2014; Azarashvili et al., 2014; Karch \& Molkentin, 2014; Chinopoulos \& Szabadkai, 2014). Mammalian $\mathrm{F}_{1} \mathrm{~F}_{\mathrm{O}}$ ATP synthase is a $\sim 600 \mathrm{kDa}$ complex of 15 subunits. The membrane portion, or $\mathrm{F}_{\mathrm{O}}$, contains a ring of 8 very hydrophobic c-subunits and subunits $\mathrm{a}, \mathrm{b}, \mathrm{e}, \mathrm{f}, \mathrm{g}$, and A6L. A stalk composed of the $\delta, \varepsilon$, and $\gamma$ subunits connects the c-subunit ring to the catalytic $F_{1}$ component made of a hexamer of alternating $a$ and $\beta$ subunits, where ATP synthesis and hydrolysis occur. Finally, a stator containing the b, d, F6, and OSCP subunits connects the lateral portion of $F_{O}$ to the top of the $F_{1}$. Movement of protons between the csubunit and the a-subunit causes rotation of the c-subunit ring, the energy of which is transferred to $F_{1}$ to synthesize ATP (Carbajo et al., 2005; Pedersen, 1994; Jonckheere et al., 2012; Walker, 2013; Wittig \& Schagger, 2009). 
Age-dependent structural and functional alterations of $\mathrm{F}_{1} \mathrm{~F}_{\mathrm{O}}$ ATP synthase in rat brain and heart mitochondria support the idea that an isolated $\mathrm{F}_{\mathrm{O}}$ portion of the ATP synthase may form the actual pore of mPTP (Guerrieri et al., 1992). In myocytes in the early embryonic mouse heart the inner membrane is leaky, but this leak is not associated with any form of cell death. However, by mid-embryonic stage, the leak is closed (Hom et al., 2011). This closure coincides with activation of complex I of the electron transport chain, assembly of electron transport chain supercomplexes called respirasomes, and activation of oxidative phosphorylation (Beutner et al., 2014). These changes cause a fall in mitochondrial-derived ROS that signals the myocyte to undergo further differentiation (Hom et al., 2011). The evidence that this developmentally regulated leak is the MPTP comes from studies that show that manipulating mPTP changes the course of cardiac development. Indeed, pharmacologically inhibiting mPTP with cyclosporine A or deleting CypD enhances myocyte differentiation, while in contrast opening MPTP inhibits differentiation (Hom et al., 2011). These findings have been confirmed in cardiac stem cells (Cho et al., 2014; Fujiwara et al., 2011).

Even after the onset of respiration, the $\mathrm{F}_{\mathrm{O}}$ still remains partially leaky at 3 months in the membranes of heart mitochondria perhaps because it lacks an equivalent complement of $F_{1}$. During the period from 3 to 12 months, the level of $F_{1}$ increases along with an increase in ATPase activity and this accompanies a decrease in proton leak consequent to binding of $\mathrm{F}_{1}$ to $\mathrm{F}_{\mathrm{O}}$. In contrast, in aging heart in animals from 12 to 24 months, decreases of $\mathrm{F}_{1}$ content with respect to that observed for $\mathrm{F}_{\mathrm{O}}$ are detected, suggesting the presence of lone $\mathrm{F}_{\mathrm{O}}$ leak channels and the propensity to undergo PT in these aging mitochondria (Guerrieri et al., 1992).

To determine if the membrane portion of the $\mathrm{F}_{1} \mathrm{~F}_{\mathrm{O}}$ ATP synthase comprises a cell death regulatory moiety that could produce PT under cell stress, the Pinton group performed different measures of cell death and PTafter c-subunit expression levels were genetically manipulated by depletion or overexpression of c-subunit isomers in HeLa cells (Bonora et al., 2013). Proliferating cell lines rely on glycolysis for ATP production in normal glucosecontaining medium, therefore depleting the c-subunit did not alter ATP levels in the cells. Depletion of the c-subunit, however, prevented CsA-sensitive PT measured by the calceincobalt quench technique and by mitochondrial morphological analysis. Cell death brought on by $\mathrm{H}_{2} \mathrm{O}_{2}$ was also attenuated by c-subunit depletion as was cell death in neurons under conditions of excitotoxicity.

Although the above study indicated that the $\mathrm{F}_{1} \mathrm{~F}_{\mathrm{O}}$ ATP synthase c-subunit was an important component of the mPTP (Bonora et al., 2013), this work did not directly determine what portion of ATP synthase could induce channel activity. Subsequent to that publication, work from the Bernardi group suggested that the mPT pore could only form from dimers of ATP synthase (Giorgio et al., 2013), demonstrating mPTP-like channel activity from purified dimers, and not monomers, of ATP synthase. However, the actual pore portion of the mPTP in this model remained to be determined. 


\section{Evidence that the c-subunit of ATP synthase creates the high conductance mPTP pore}

More recent experiments have directly tested the hypothesis that the main membrane embedded portion of mammalian $\mathrm{F}_{1} \mathrm{~F}_{\mathrm{O}}$ ATP synthase, i.e. the c-subunit ring, forms the pore of the mPTP (Alavian et al., 2014; Azarashvili et al., 2014). Purified, reconstituted c-subunit has been shown previously to form a channel with a diameter of $2.3 \mathrm{~nm}$ which allows molecules up to $1.5 \mathrm{kDa}$ to pass, similar to PT (McGeoch \& Guidotti, 1997; McGeoch et al., 2000; McGeoch \& McGeoch, 2008). In agreement, our own electrophysiologic recordings of the purified mitochondrial c-subunit yield a multi-conductance, voltage dependent channel with prominent subconductance states. Recordings contain a 100-pS conductance, which appears to be a subconductance state of a multiconductance activity rather than a separate conductance. Peak single channel conductances of $\sim 1.5-2 \mathrm{nS}$ are similar to activity described previously for the MCC (Kinnally et al., 1989). Also consistent with MCC, channel activity often but not always demonstrates negative rectification. At very positive patch pipette potentials of over $100 \mathrm{mV}$, single channel conductances of $\sim 1.5 \mathrm{nS}$ and $\sim 2 \mathrm{nS}$ are also consistently observed, presumably because the prolonged open states at negative potentials prevent observation of discrete single channel events that can therefore more easily be observed at positive potentials. This finding is in keeping with similar activity observed previously for mPTP (Petronilli et al., 1989).

Voltage dependence is an inherent property of the channel (Borjesson \& Elinder, 2008) and is not dependent on the mitochondrial inner membrane potential or on the solutions used to record the currents. It is measured by varying the voltage across the membrane (the command or holding voltage). Published current-voltage (I-V) curves of mPTP (Petronilli et al., 1989; Kinnally et al., 1989) reveal that the channel shows both non-rectifying conductances and a rectification in the I-V either in the positive or negative voltage range, consistent with I-V plots of our recent recordings of the purified c-subunit (Alavian et al., 2014).

\section{$F_{1}$ regulates biophysical characteristics of the purified c-subunit}

Purified c-subunit protein reconstituted into liposomes clearly lacks extrinsic regulatory moieties that are important for mPTP opening. The effects of $\mathrm{Ca}^{2+}$, a critical regulatory molecule, demonstrate this property. $\mathrm{Ca}^{2+}$ binding sites have not been detected in mitochondrial $\mathrm{F}_{\mathrm{O}}$, perhaps because mammalian c-subunits lack the formyl Met at the Nterminus to which $\mathrm{Ca}^{2+}$ binds to E.coli or chloroplast $\mathrm{F}_{1} \mathrm{~F}_{\mathrm{O}}$ ATP synthase c-subunits (Zakharov et al., 1996). Although $\mathrm{Ca}^{2+}$ can bind to specific, low affinity and moderate capacity sites on the $\beta$-subunit of mitochondrial $\mathrm{F}_{1}$ ATP synthase (Hubbard \& McHugh, 1996), sites in other ATP synthase-interacting regulatory molecules may also be important for regulation by $\mathrm{Ca}^{2+}$ and other agents (Beutner et al., 1998; Beutner et al., 1996).

To determine the location of the c-subunit pore regulators, mitochondrial recordings were carried out using purified mitochondrial and $\mathrm{F}_{1} \mathrm{~F}_{\mathrm{O}}$ ATP synthase preparations. In these studies, the absence of an effect of a modulator was taken as an indication that the ligand or binding site for that modulator had been removed by the purification process. These studies 
demonstrated that the c-subunit leak channel is regulated by the overlying $F_{1}$ and peripheral proteins (Alavian et al., 2014). In mitochondria or in inner membrane preparations lacking the outer membrane (such as submitochondrial vesicles, SMVs) (Chen et al., 2004) but containing the intact ATP synthase, $\mathrm{Ca}^{2+}$ activates the leak channel while CsA and ATP/ADP inhibit it, suggesting that the $\mathrm{Ca}^{2+}$ and CsA sensitive sites are present in these preparations. In contrast, removal of the $\mathrm{F}_{1}$ and other peripheral membrane proteins by urea treatment of the inner membrane or removal of CypD by purification of ATP synthase monomers abrogates regulation of the c-subunit channel by $\mathrm{CsA}$ and $\mathrm{Ca}^{2+}$ and greatly diminishes sensitivity to ATP/ADP. These studies suggest that the $\mathrm{CypD} / \mathrm{Ca}^{2+}$ binding site is contained within or associated with the $\mathrm{F}_{1}$ portion of the ATP synthase and that a second, low-affinity ATP binding site exists in the $\mathrm{F}_{\mathrm{O}}$. These results are consistent with reports identifying the binding site of CypD and benzodiazepine 423, an ATP synthase-inhibitory and mPTP-sensitizing agent, on OSCP (Giorgio et al., 2009), and suggest that the assembly of $\mathrm{F}_{1} \mathrm{~F}_{\mathrm{O}}$ ATP synthase into monomers, dimers, and higher order oligomers may regulate the formation of the mPTP (Giorgio et al., 2013).

Channel activity of the purified c-subunit is inhibited by $F_{1}$, suggesting a structural rearrangement whereby the stalk and $F_{1}$ of the ATP synthase inhibits opening of the csubunit channel, aided by $\mathrm{ADP} / \mathrm{ATP} / \mathrm{Bcl}-\mathrm{x}_{\mathrm{L}}$ binding to the $\beta$-subunit and opposed by $\mathrm{CypD} / \mathrm{Ca}^{2+}$ interaction with OSCP (Fig. 5). In order to demonstrate this further, mitochondria were treated with $\mathrm{Ca}^{2+}$ following which the $\mathrm{F}_{1} \mathrm{~F}_{\mathrm{O}}$ ATP synthase was immunoprecipitated using an antibody directed at the $\mathrm{F}_{1}$. These studies determined that $\mathrm{Ca}^{2+}$ exposure destabilizes the connection between the stalk and the c-subunit, disrupting protein/ protein interaction between the c-subunit and $\mathrm{F}_{1}$ (Fig. 5). The model suggests that the channel of the mPTP forms within the c-subunit ring itself upon reversible CypD and $\mathrm{Ca}^{2+}$ dependent movement of the stalk away from the c-subunit (Alavian et al., 2014).

Loss of protein/protein interaction between $\mathrm{F}_{1}$ and $\mathrm{F}_{\mathrm{O}}$ requires only mild $(60 \mu \mathrm{M}) \mathrm{Ca}^{2+}$ elevations in the bath which initiates what may indeed be reversible PT (Alavian et al., 2014). This concentration is well within the range of physiological $\mathrm{Ca}^{2+}$ concentrations found within the mitochondrial matrix (Csordas et al., 2001; Rizzuto et al., 2000; Rizzuto \& Pozzan, 2006) or concentrations measured adjacent to the mitochondria in $\mathrm{Ca}^{2+}$ microdomains at the ER or plasma membrane (Rizzuto et al., 2009; Schneggenburger \& Neher, 2005). That the loss of protein/protein interaction between $\mathrm{F}_{1}$ and $\mathrm{F}_{\mathrm{O}}$ is likely to be reversible has been shown upon chelation of $\mathrm{Ca}^{2+}$ in mitoplasts (Beutner et al., 1998), intact mitochondria (Roestenberg et al., 2012), intact neurons (Jonas et al., 1999) as well as in reconstituted dimers of F-ATP synthase (Gomez et al., 2007), suggesting that the $F_{1}$ and the c-subunit can recombine to close the mPTP, reforming intact $\mathrm{F}_{1} \mathrm{~F}_{\mathrm{O}}$ ATP synthase and reinitiating enzymatic function (Pedersen \& Hullihen, 1978). However, under certain conditions, this separation may become irreversible, forming pathophysiological PT (with MOMP).

Regulators of the mPTP may act directly on the $\mathrm{F}_{1} \mathrm{~F}_{\mathrm{O}}$ ATP synthase itself or may involve many known and undiscovered proteins that interact directly or indirectly with ATP synthase, as suggested in previous reports (Pasdois et al., 2013; Beutner et al., 1996; Chen et al., 2004) $\mathrm{F}_{1}$ has binding sites that accommodate the effects of $\mathrm{Ca}^{2+}, \mathrm{Mg}^{2+}$, adenine 
nucleotides and $\mathrm{P}_{\mathrm{i}}$; and through CypD (un)binding those of $\mathrm{H}^{+}$, CsA and possibly of oxidants (Kruse et al., 2008; Giorgio et al., 2010). The new model of mPTP incorporates direct or indirect interaction with all known inducers, inhibitors and modulators of pore function.

\section{Structural location of the pore within the c-subunit ring}

The exact location of the pore within the c-subunit is becoming increasingly understood. We suggest that it is likely that the leak is located within the central portion of the c-subunit ring. We find that the c-subunit ring expands when it conducts ions, making it likely that the pore is formed within the expanding ring. Using fluorescent tetracysteine display with the placement of cysteine pairs on all c-subunit monomers within the ring, our studies show that $\mathrm{Ca}^{2+}$ influx into cells causes a decrease in fluorescence consistent with expansion of the ring, while $\mathrm{CsA}$ increases fluorescence consistent with a decrease in ring diameter (Alavian et al., 2014). Mutations targeted to four highly conserved glycines within the first (N terminus) alpha-helical region of the c-subunit (Norris et al., 1992) are known to increase the diameter of the ring and we find that these mutations increase average single-channel conductance compared with WTc-subunit rings (Alavian et al., 2014). When viewed from the inter-membrane space, the denuded c-subunit oligomer appears to have a central porelike structure that is normally obscured by the $\mathrm{F}_{1}$ stalk components, suggesting that the mouth of the pore may be unmasked by removal of $F_{1}$ (Pogoryelov et al., 2007). Although it has been suggested that phospholipids occupy the central cavity of the c-subunit ring in $\mathrm{F}_{1} \mathrm{~F}_{\mathrm{O}}$ ATP synthases from different species (Oberfeld et al., 2006; Meier et al., 2001; Matthies et al., 2009) other evidence provides for formation of a proteolipid or proteophospholipid channel structure within the central lipid region upon activation of PT (Abramov et al., 2007; Elustondo et al., 2013; Azarashvili et al., 2014; McGeoch \& McGeoch, 2008; Pavlov et al., 2005). Polyhydroxybutyrate (PHB) is a polymer distinct from the lipids that may form an ion channel within the lipid milieu if mammalian c-subunit is indeed filled with PHB (Elustondo et al., 2013; Pavlov et al., 2005). Data suggest a working model whereby the c-subunit pore forms within the proteolipid milieu (for example by elevated matrix $\mathrm{Ca}^{2+}$ ) whereupon the ring expands and $\mathrm{F}_{1}$ shifts; the pore is closed by a decrease in diameter of the ring and inactivated by binding of the $\mathrm{F}_{1}$ components to the ring (Fig. 5). The details of these changes and their regulation remain a work in progress.

\section{How does physiological regulation of the MPTP alter synaptic plasticity? Conclusions and plans for the future}

Closure of a leak within the inner mitochondrial membrane in the presence of $\mathrm{Bcl}-\mathrm{x}_{\mathrm{L}}$ aids actively firing neurons to increase neurotransmitter release (Li et al., 2008; Li et al., 2013), consistent with a correlation between the increase in metabolic efficiency and the long-term higher efficacy of synaptic transmission found in $\mathrm{Bcl}-\mathrm{x}_{\mathrm{L}}$ expressing neurons. In contrast, opening of a Bcl- $\mathrm{x}_{\mathrm{L}}$-regulated inner membrane leak decreases metabolic efficiency, predisposes neurons to death and causes a decline in neurotransmitter release, consistent with a role for the c-subunit channel (putative mPTP) not only in neuronal death but in synaptic dysfunction. Neurons lacking Bcl- $\mathrm{x}_{\mathrm{L}}$ display a fluctuating mitochondrial inner 
membrane potential and a marked depolarization in the presence of the ATP synthase inhibitor oligomycin (Chen et al., 2011). Current data also provide indirect support for regulation by $\mathrm{Bcl}-\mathrm{x}_{\mathrm{L}}$ of the $\mathrm{F}_{1} \mathrm{~F}_{\mathrm{O}}$ ATP synthase during healthy synaptic events, but direct observation of fluorescently labeled c-subunit and/or labeled $\mathrm{F}_{1}$ will determine how the putative mPTP channel behaves during actual synaptic events and in synapses undergoing plasticity.

\section{References}

Abramov AY, Fraley C, Diao CT, Winkfein R, Colicos MA, Duchen MR, French RJ, Pavlov E. Targeted polyphosphatase expression alters mitochondrial metabolism and inhibits calciumdependent cell death. Proc Natl Acad Sci U S A. 2007; 104:18091-18096. DOI: 10.1073/pnas. 0708959104 [PubMed: 17986607]

Adams JM, Cory S. The bcl-2 apoptotic switch in cancer development and therapy. Oncogene. 2007; 26:1324-1337. [PubMed: 17322918]

Alavian KN, Li H, Collis L, Bonanni L, Zeng L, Sacchetti S, Lazrove E, Nabili P, Flaherty B, Graham M, Chen Y, Messerli SM, Mariggio MA, Rahner C, McNay E, Shore GC, Smith PJ, Hardwick JM, Jonas EA. Bcl-xL regulates metabolic efficiency of neurons through interaction with the mitochondrial F1FO ATP synthase. Nat Cell Biol. 2011; 13:1224-1233. DOI: 10.1038/ncb2330 [PubMed: 21926988]

Alavian KN, Beutner G, Lazrove E, Sacchetti S, Park HA, Licznerski P, Li H, Nabili P, Hockensmith $\mathrm{K}$, Graham M, Porter GA Jr, Jonas EA. An uncoupling channel within the c-subunit ring of the F1FO ATP synthase is the mitochondrial permeability transition pore. Proc Natl Acad Sci U S A. 2014; 111:10580-10585. DOI: 10.1073/pnas.1401591111 [PubMed: 24979777]

Antonsson B, Montessuit S, Lauper S, Eskes R, Martinou JC. Bax oligomerization is required for channel-forming activity in liposomes and to trigger cytochrome c release from mitochondria. Biochem J. 2000; 345(Pt 2):271-278. [PubMed: 10620504]

Azarashvili T, Odinokova I, Bakunts A, Ternovsky V, Krestinina O, Tyynela J, Saris NE. Potential role of subunit $\mathrm{c}$ of FOF1-ATPase and subunit $\mathrm{c}$ of storage body in the mitochondrial permeability transition. Effect of the phosphorylation status of subunit $\mathrm{c}$ on pore opening. Cell Calcium. 2014; 55:69-77. DOI: 10.1016/j.ceca.2013.12.002 [PubMed: 24380588]

Beal MF. Mitochondria and neurodegeneration. Novartis Found Symp. 2007; 287:183-192. discussion 192-186. [PubMed: 18074639]

Berman SB, Chen YB, Qi B, McCaffery JM, Rucker EB 3rd, Goebbels S, Nave KA, Arnold BA, Jonas EA, Pineda FJ, Hardwick JM. Bcl-x L increases mitochondrial fission, fusion, and biomass in neurons. J Cell Biol. 2009; 184:707-719. published online EpubMar 9. [PubMed: 19255249]

Bernardi P. Mitochondrial transport of cations: channels, exchangers, and permeability transition. Physiol Rev. 1999; 79:1127-1155. [PubMed: 10508231]

Beutner G, Ruck A, Riede B, Welte W, Brdiczka D. Complexes between kinases, mitochondrial porin and adenylate translocator in rat brain resemble the permeability transition pore. FEBS Lett. 1996; 396:189-195. published online EpubNov 4. [PubMed: 8914985]

Beutner G, Ruck A, Riede B, Brdiczka D. Complexes between porin, hexokinase, mitochondrial creatine kinase and adenylate translocator display properties of the permeability transition pore. Implication for regulation of permeability transition by the kinases. Biochim Biophys Acta. 1998; 1368:7-18. published online EpubJan 5. [PubMed: 9459579]

Beutner G, Eliseev RA, Porter GA Jr. Initiation of electron transport chain activity in the embryonic heart coincides with the activation of mitochondrial complex 1 and the formation of supercomplexes. PLoS One. 2014; 9:e113330.doi: 10.1371/journal.pone.0113330 [PubMed: 25427064]

Bonora M, Bononi A, De Marchi E, Giorgi C, Lebiedzinska M, Marchi S, Patergnani S, Rimessi A, Suski JM, Wojtala A, Wieckowski MR, Kroemer G, Galluzzi L, Pinton P. Role of the c subunit of the FO ATP synthase in mitochondrial permeability transition. Cell Cycle. 2013; 12:674-683. DOI: 10.4161/cc.23599 [PubMed: 23343770] 
Bonora M, Wieckowski MR, Chinopoulos C, Kepp O, Kroemer G, Galluzzi L, Pinton P. Molecular mechanisms of cell death: central implication of ATP synthase in mitochondrial permeability transition. Oncogene. 2014; Odoi: 10.1038/onc.2014.96

Borjesson SI, Elinder F. Structure, function, and modification of the voltage sensor in voltage-gated ion channels. Cell Biochem Biophys. 2008; 52:149-174. DOI: 10.1007/s12013-008-9032-5 [PubMed: 18989792]

Brand MD. The efficiency and plasticity of mitochondrial energy transduction. Biochem Soc Trans. 2005; 33:897-904. published online EpubNov. [PubMed: 16246006]

Carbajo RJ, Kellas FA, Runswick MJ, Montgomery MG, Walker JE, Neuhaus D. Structure of the F1binding domain of the stator of bovine F1Fo-ATPase and how it binds an alpha-subunit. J Mol Biol. 2005; 351:824-838. DOI: 10.1016/j.jmb.2005.06.012 [PubMed: 16045926]

Chen C, Ko Y, Delannoy M, Ludtke SJ, Chiu W, Pedersen PL. Mitochondrial ATP synthasome: threedimensional structure by electron microscopy of the ATP synthase in complex formation with carriers for Pi and ADP/ATP. J Biol Chem. 2004; 279:31761-31768. published online EpubJul 23. [PubMed: 15166242]

Chen YB, Aon MA, Hsu YT, Soane L, Teng X, McCaffery JM, Cheng WC, Qi B, Li H, Alavian KN, Dayhoff-Brannigan M, Zou S, Pineda FJ, O'Rourke B, Ko YH, Pedersen PL, Kaczmarek LK, Jonas EA, Hardwick JM. Bcl-xL regulates mitochondrial energetics by stabilizing the inner membrane potential. J Cell Biol. 2011; 195:263-276. published online EpubOct 17. [PubMed: 21987637]

Chinopoulos C, Szabadkai G. What Makes You Can also Break You, Part III: Mitochondrial Permeability Transition Pore Formation by an Uncoupling Channel within the C-Subunit Ring of the F1FO ATP Synthase? Frontiers oncol. 2014; 4:235.doi: 10.3389/fonc.2014.00235

Cho SW, Park JS, Heo HJ, Park SW, Song S, Kim I, Han YM, Yamashita JK, Youm JB, Han J, Koh GY. Dual modulation of the mitochondrial permeability transition pore and redox signaling synergistically promotes cardiomyocyte differentiation from pluripotent stem cells. J Am Heart Assoc. 2014; 3:e000693.doi: 10.1161/JAHA.113.000693 [PubMed: 24627421]

Chouhan AK, Ivannikov MV, Lu Z, Sugimori M, Llinas RR, Macleod GT. Cytosolic calcium coordinates mitochondrial energy metabolism with presynaptic activity. J Neurosci. 2012; 32:1233-1243. DOI: 10.1523/JNEUROSCI.1301-11.2012 [PubMed: 22279208]

Crompton M. The mitochondrial permeability transition pore and its role in cell death. Biochem J. 1999; 341:233-249. [PubMed: 10393078]

Crompton M, Virji S, Ward JM. Cyclophilin-D binds strongly to complexes of the voltage-dependent anion channel and the adenine nucleotide translocase to form the permeability transition pore. Eur J Biochem. 1998; 258:729-735. [PubMed: 9874241]

Csordas G, Thomas AP, Hajnoczky G. Calcium signal transmission between ryanodine receptors and mitochondria in cardiac muscle. Trends cardiovasc med. 2001; 11:269-275. published online EpubOct. [PubMed: 11709280]

De Marchi E, Bonora M, Giorgi C, Pinton P. The mitochondrial permeability transition pore is a dispensable element for mitochondrial calcium efflux. Cell Calcium. 2014; 56:1-13. DOI: 10.1016/j.ceca.2014.03.004 [PubMed: 24755650]

Dejean LM, Martinez-Caballero S, Guo L, Hughes C, Teijido O, Ducret T, Ichas F, Korsmeyer SJ, Antonsson B, Jonas EA, Kinnally KW. Oligomeric bax is a component of the putative cytochrome c release channel MAC, mitochondrial apoptosis-induced channel. Mol Biol Cell. 2005; 16:24242432. [PubMed: 15772159]

Dejean LM, Martinez-Caballero S, Manon S, Kinnally KW. Regulation of the mitochondrial apoptosisinduced channel, MAC, by BCL-2 family proteins. Biochim Biophys Acta. 2006; 1762:191-201. published online EpubFeb. [PubMed: 16055309]

Di Lisa F, Carpi A, Giorgio V, Bernardi P. The mitochondrial permeability transition pore and cyclophilin D in cardioprotection. Biochim Biophys Acta. 2011; 1813:1316-1322. DOI: 10.1016/ j.bbamcr.2011.01.031 [PubMed: 21295622]

Dodson MW, Guo M. Pink1, Parkin, DJ-1 and mitochondrial dysfunction in Parkinson's disease. Curr Opin Neurobiol. 2007; 17:331-337. published online EpubJun. [PubMed: 17499497] 
Elrod JW, Wong R, Mishra S, Vagnozzi RJ, Sakthievel B, Goonasekera SA, Karch J, Gabel S, Farber J, Force T, Brown JH, Murphy E, Molkentin JD. Cyclophilin D controls mitochondrial poredependent $\mathrm{Ca}(2+)$ exchange, metabolic flexibility, and propensity for heart failure in mice. J Clin Invest. 2010; 120:3680-3687. DOI: 10.1172/JCI43171 [PubMed: 20890047]

Elustondo PA, Angelova PR, Kawalec M, Michalak M, Kurcok P, Abramov AY, Pavlov EV. Polyhydroxybutyrate targets mammalian mitochondria and increases permeability of plasmalemmal and mitochondrial membranes. PLoS One. 2013; 8:e75812.doi: 10.1371/ journal.pone.0075812 [PubMed: 24086638]

Friel DD, Tsien RW. An FCCP-sensitive Ca2+ store in bullfrog sympathetic neurons and its participation in stimulus-evoked changes in [Ca2+]i. J Neurosci. 1994; 14:4007-4024. [PubMed: 8027759]

Fujiwara M, Yan P, Otsuji TG, Narazaki G, Uosaki H, Fukushima H, Kuwahara K, Harada M, Matsuda H, Matsuoka S, Okita K, Takahashi K, Nakagawa M, Ikeda T, Sakata R, Mummery CL, Nakatsuji N, Yamanaka S, Nakao K, Yamashita JK. Induction and enhancement of cardiac cell differentiation from mouse and human induced pluripotent stem cells with cyclosporin-A. PLoS One. 2011; 6:e16734.doi: 10.1371/journal.pone.0016734 [PubMed: 21364991]

Galonek HL, Hardwick JM. Upgrading the BCL-2 network.[comment]. Nat Cell Biol. 2006; 8:13171319. [PubMed: 17139279]

Giorgio V, Bisetto E, Soriano ME, Dabbeni-Sala F, Basso E, Petronilli V, Forte MA, Bernardi P, Lippe G. Cyclophilin D modulates mitochondrial F0F1-ATP synthase by interacting with the lateral stalk of the complex. J Biol Chem. 2009; 284:33982-33988. published online EpubDec 4. [PubMed: 19801635]

Giorgio V, Soriano ME, Basso E, Bisetto E, Lippe G, Forte MA, Bernardi P. Cyclophilin D in mitochondrial pathophysiology. Biochim Biophys Acta. 2010; 1797:1113-1118. published online EpubJun-Jul. [PubMed: 20026006]

Giorgio V, von Stockum S, Antoniel M, Fabbro A, Fogolari F, Forte M, Glick GD, Petronilli V, Zoratti M, Szabo I, Lippe G, Bernardi P. Dimers of mitochondrial ATP synthase form the permeability transition pore. Proc Natl Acad Sci U S A. 2013; 110:5887-5892. DOI: 10.1073/pnas.1217823110 [PubMed: 23530243]

Gomez L, Thibault H, Gharib A, Dumont JM, Vuagniaux G, Scalfaro P, Derumeaux G, Ovize M. Inhibition of mitochondrial permeability transition improves functional recovery and reduces mortality following acute myocardial infarction in mice. Am J Physiol Heart Circ Physiol. 2007; 293:H1654-H1661. DOI: 10.1152/ajpheart.01378.2006 [PubMed: 17557911]

Gottlieb E, Armour SM, Thompson CB. Mitochondrial respiratory control is lost during growth factor deprivation. Proc Natl Acad Sci U S A. 2002; 99:12801-12806. [PubMed: 12228733]

Green DR, Kroemer G. The pathophysiology of mitochondrial cell death. Science. 2004; 305:626-629. [PubMed: 15286356]

Griffiths EJ, Halestrap AP. Mitochondrial non-specific pores remain closed during cardiac ischaemia, but open upon reperfusion. Biochem J. 1995; 307(Pt 1):93-98. published online EpubApr 1. [PubMed: 7717999]

Guerrieri F, Capozza G, Kalous M, Papa S. Age-related changes of mitochondrial F0F1 ATP synthase. Ann N Y Acad Sci. 1992; 671:395-402. published online EpubNov 30. [PubMed: 1288336]

Gunter TE, Sheu SS. Characteristics and possible functions of mitochondrial $\mathrm{Ca}(2+)$ transport mechanisms. Biochim Biophys Acta. 2009; 1787:1291-1308. DOI: 10.1016/j.bbabio.2008.12.011 [PubMed: 19161975]

Gutierrez-Aguilar M, Douglas DL, Gibson AK, Domeier TL, Molkentin JD, Baines CP. Genetic manipulation of the cardiac mitochondrial phosphate carrier does not affect permeability transition. J Mol Cell Cardiol. 2014; 72:316-325. DOI: 10.1016/j.yjmcc.2014.04.008 [PubMed: 24768964]

Halestrap AP, Davidson AM. Inhibition of Ca2(+)-induced large-amplitude swelling of liver and heart mitochondria by cyclosporin is probably caused by the inhibitor binding to mitochondrial-matrix peptidyl-prolyl cis-trans isomerase and preventing it interacting with the adenine nucleotide translocase. Biochem J. 1990; 268:153-160. published online EpubMay 15. [PubMed: 2160810] 
Hausenloy D, Wynne A, Duchen M, Yellon D. Transient mitochondrial permeability transition pore opening mediates preconditioning-induced protection. Circulation. 2004; 109:1714-1717. DOI: 10.1161/01.CIR.0000126294.81407.7D [PubMed: 15066952]

Haworth RA, Hunter DR. The Ca2+-induced membrane transition in mitochondria. II. Nature of the Ca2+ trigger site. Arch Biochem Biophys. 1979; 195:460-467. published online EpubJul. [PubMed: 38751]

Hickman JA, Hardwick JM, Kaczmarek LK, Jonas EA. Bcl-xL inhibitor ABT-737 reveals a dual role for Bcl-xL in synaptic transmission. J Neurophysiol. 2008; 99:1515-1522. published online EpubMar. [PubMed: 18160428]

Hockenbery D, Nunez G, Milliman C, Schreiber RD, Korsmeyer SJ. Bcl-2 is an inner mitochondrial membrane protein that blocks programmed cell death. Nature. 1990; 348:334-336. published online EpubNov 22. [PubMed: 2250705]

Holmstrom KM, Marina N, Baev AY, Wood NW, Gourine AV, Abramov AY. Signalling properties of inorganic polyphosphate in the mammalian brain. Nat Commun. 2013; 4:1362.doi: 10.1038/ ncomms2364 [PubMed: 23322050]

Hom JR, Quintanilla RA, Hoffman DL, de Mesy Bentley KL, Molkentin JD, Sheu SS, Porter GA Jr. The permeability transition pore controls cardiac mitochondrial maturation and myocyte differentiation. Dev Cell. 2011; 21:469-478. DOI: 10.1016/j.devcel.2011.08.008 [PubMed: 21920313]

Hubbard MJ, McHugh NJ. Mitochondrial ATP synthase F1-beta-subunit is a calcium-binding protein. FEBS Lett. 1996; 391:323-329. published online EpubAug 12. [PubMed: 8764999]

Hunter DR, Haworth RA. The Ca2+-induced membrane transition in mitochondria. I. The protective mechanisms. Arch Biochem Biophys. 1979; 195:453-459. published online EpubJul. [PubMed: 383019]

Huser J, Blatter LA. Fluctuations in mitochondrial membrane potential caused by repetitive gating of the permeability transition pore. Biochem J. 1999; 343(Pt 2):311-317. published online EpubOct 15. [PubMed: 10510294]

Ichas F, Mazat JP. From calcium signaling to cell death: two conformations for the mitochondrial permeability transition pore. Switching from low- to high-conductance state. Biochim Biophys Acta. 1998; 1366:33-50. published online EpubAug 10. [PubMed: 9714722]

Jonas E. BCL-xL regulates synaptic plasticity. Mol Interv. 2006; 6:208-222. [PubMed: 16960143]

Jonas EA. Molecular participants in mitochondrial cell death channel formation during neuronal ischemia. Exp Neurol. 2009; 218:203-212. published online EpubAug. [PubMed: 19341732]

Jonas EA, Knox RJ, Kaczmarek LK. Giga-ohm seals on intracellular membranes: a technique for studying intracellular ion channels in intact cells. Neuron. 1997; 19:7-13. [PubMed: 9247259]

Jonas EA, Buchanan J, Kaczmarek LK. Prolonged activation of mitochondrial conductances during synaptic transmission. Science. 1999; 286:1347-1350. [PubMed: 10558987]

Jonas EA, Hoit D, Hickman JA, Brandt TA, Polster BM, Fannjiang Y, McCarthy E, Montanez MK, Hardwick JM, Kaczmarek LK. Modulation of synaptic transmission by the BCL-2 family protein BCL-xL. J Neurosci. 2003; 23:8423-8431. [PubMed: 12968005]

Jonckheere AI, Smeitink JA, Rodenburg RJ. Mitochondrial ATP synthase: architecture, function and pathology. J Inherit Metab Dis. 2012; 35:211-225. DOI: 10.1007/s10545-011-9382-9 [PubMed: 21874297]

Jouaville LS, Ichas F, Mazat JP. Modulation of cell calcium signals by mitochondria. Mol Cell Biochem. 1998; 184:371-376. published online EpubJul. [PubMed: 9746331]

Karch J, Molkentin JD. Identifying the components of the elusive mitochondrial permeability transition pore. Proc Natl Acad Sci U S A. 2014; 111:10396-10397. DOI: 10.1073/pnas. 1410104111 [PubMed: 25002521]

Kim H, Rafiuddin-Shah M, Tu HC, Jeffers JR, Zambetti GP, Hsieh JJ, Cheng EH. Hierarchical regulation of mitochondrion-dependent apoptosis by BCL-2 subfamilies.[see comment]. Nat Cell Biol. 2006; 8:1348-1358. [PubMed: 17115033]

Kinnally KW, Campo ML, Tedeschi H. Mitochondrial channel activity studied by patch-clamping mitoplasts. J Bioenerg Biomembr. 1989; 21:497-506. [PubMed: 2478535] 
Kinnally KW, Martinez-Caballero S, Dejean LM. Detection of the mitochondrial apoptosis-induced channel (MAC) and its regulation by Bcl-2 family proteins. Current protoc toxicol. 2006 Chapter 2, Unit2 12; published online EpubDec.

Kinnally KW, Peixoto PM, Ryu SY, Dejean LM. Is mPTP the gatekeeper for necrosis, apoptosis, or both? Biochim Biophys Acta. 2011; 1813:616-622. DOI: 10.1016/j.bbamcr.2010.09.013 [PubMed: 20888866]

Kokoszka JE, Waymire KG, Levy SE, Sligh JE, Cai J, Jones DP, MacGregor GR, Wallace DC. The ADP/ATP translocator is not essential for the mitochondrial permeability transition pore.[see comment]. Nature. 2004; 427:461-465. [PubMed: 14749836]

Korge P, Yang L, Yang JH, Wang Y, Qu Z, Weiss JN. Protective role of transient pore openings in calcium handling by cardiac mitochondria. J Biol Chem. 2011; 286:34851-34857. DOI: 10.1074/ jbc.M111.239921 [PubMed: 21859717]

Kowaltowski AJ, Naia-da-Silva ES, Castilho RF, Vercesi AE. Ca2+-stimulated mitochondrial reactive oxygen species generation and permeability transition are inhibited by dibucaine or $\mathrm{Mg} 2+\mathrm{Arch}$ Biochem Biophys. 1998; 359:77-81. DOI: 10.1006/abbi.1998.0870 [PubMed: 9799563]

Kruse SE, Watt WC, Marcinek DJ, Kapur RP, Schenkman KA, Palmiter RD. Mice with mitochondrial complex I deficiency develop a fatal encephalomyopathy. Cell Metab. 2008; 7:312-320. DOI: 10.1016/j.cmet.2008.02.004 [PubMed: 18396137]

Kwong JQ, Davis J, Baines CP, Sargent MA, Karch J, Wang X, Huang T, Molkentin JD. Genetic deletion of the mitochondrial phosphate carrier desensitizes the mitochondrial permeability transition pore and causes cardiomyopathy. Cell Death Differ. 2014; 21:1209-1217. DOI: 10.1038/ cdd.2014.36 [PubMed: 24658400]

Leung AW, Halestrap AP. Recent progress in elucidating the molecular mechanism of the mitochondrial permeability transition pore. Biochim Biophys Acta. 2008; 1777:946-952. DOI: 10.1016/j.bbabio.2008.03.009 [PubMed: 18407825]

Li H, Chen Y, Jones AF, Sanger RH, Collis LP, Flannery R, McNay EC, Yu T, Schwarzenbacher R, Bossy B, Bossy-Wetzel E, Bennett MV, Pypaert M, Hickman JA, Smith PJ, Hardwick JM, Jonas EA. Bcl-xL induces Drp1-dependent synapse formation in cultured hippocampal neurons. Proc Natl Acad Sci U S A. 2008; 105:2169-2174. [PubMed: 18250306]

Li Z, Jo J, Jia JM, Lo SC, Whitcomb DJ, Jiao S, Cho K, Sheng M. Caspase-3 activation via mitochondria is required for long-term depression and AMPA receptor internalization. Cell. 2010; 141:859-871. published online EpubMay 28. [PubMed: 20510932]

Li H, Alavian KN, Lazrove E, Mehta N, Jones A, Zhang P, Licznerski P, Graham M, Uo T, Guo J, Rahner C, Duman RS, Morrison RS, Jonas EA. A bcl-xL-Drp1 complex regulates synaptic vesicle membrane dynamics during endocytosis. Nat Cell Biol. 2013; 15:773-785. DOI: 10.1038/ncb2791 [PubMed: 23792689]

Lopreiato R, Giacomello M, Carafoli E. The plasma membrane calcium pump: new ways to look at an old enzyme. J Biol Chem. 2014; 289:10261-10268. DOI: 10.1074/jbc.O114.555565 [PubMed: 24570005]

Martinez-Caballero S, Dejean LM, Jonas EA, Kinnally KW. The role of the mitochondrial apoptosis induced channel MAC in cytochrome c release. J Bioenerg Biomembr. 2005; 37:155-164. [PubMed: 16167172]

Matthies D, Preiss L, Klyszejko AL, Muller DJ, Cook GM, Vonck J, Meier T. The c13 ring from a thermoalkaliphilic ATP synthase reveals an extended diameter due to a special structural region. J Mol Biol. 2009; 388:611-618. DOI: 10.1016/j.jmb.2009.03.052 [PubMed: 19327366]

McGeoch JE, Guidotti G. A $0.1-700 \mathrm{~Hz}$ current through a voltage-clamped pore: candidate protein for initiator of neural oscillations. Brain Res. 1997; 766:188-194. published online EpubAug 22. [PubMed: 9359602]

McGeoch JE, McGeoch MW. Entrapment of water by subunit c of ATP synthase. J Royal Soc, Interface/Roy Soc. 2008; 5:311-318. DOI: 10.1098/rsif.2007.1146

McGeoch JE, McGeoch MW, Mao R, Guidotti G. Opposing actions of cGMP and calcium on the conductance of the $\mathrm{F}(0)$ subunit c pore. Biochem Biophys Res Commun. 2000; 274:835-840. DOI: 10.1006/bbrc.2000.3231 [PubMed: 10924363] 
Meier T, Matthey U, Henzen F, Dimroth P, Muller DJ. The central plug in the reconstituted undecameric c cylinder of a bacterial ATP synthase consists of phospholipids. FEBS Lett. 2001; 505:353-356. published online EpubSep 21. [PubMed: 11576527]

Neher E, Sakaba T. Multiple roles of calcium ions in the regulation of neurotransmitter release. Neuron. 2008; 59:861-872. DOI: 10.1016/j.neuron.2008.08.019 [PubMed: 18817727]

Norris U, Karp PE, Fimmel AL. Mutational analysis of the glycine-rich region of the c subunit of the Escherichia coli F0F1 ATPase. J Bacteriol. 1992; 174:4496-4499. published online EpubJul. [PubMed: 1385593]

Oberfeld B, Brunner J, Dimroth P. Phospholipids occupy the internal lumen of the c ring of the ATP synthase of Escherichia coli. Biochemistry. 2006; 45:1841-1851. DOI: 10.1021/bi052304+ [PubMed: 16460030]

Pasdois P, Parker JE, Halestrap AP. Extent of mitochondrial hexokinase II dissociation during ischemia correlates with mitochondrial cytochrome $\mathrm{c}$ release, reactive oxygen species production, and infarct size on reperfusion. J Am Heart Assoc. 2013; 2:e005645.doi: 10.1161/JAHA.112.005645 [PubMed: 23525412]

Pavlov EV, Priault M, Pietkiewicz D, Cheng EH, Antonsson B, Manon S, Korsmeyer SJ, Mannella CA, Kinnally KW. A novel, high conductance channel of mitochondria linked to apoptosis in mammalian cells and bax expression in yeast. J Cell Biol. 2001; 155:725-731. [PubMed: 11724814]

Pavlov E, Zakharian E, Bladen C, Diao CT, Grimbly C, Reusch RN, French RJ. A large, voltagedependent channel, isolated from mitochondria by water-free chloroform extraction. Biophys J. 2005; 88:2614-2625. DOI: 10.1529/biophysj.104.057281 [PubMed: 15695627]

Pedersen PL. ATP synthase. The machine that makes ATP. Curr biol: CB. 1994; 4:1138-1141. published online EpubDec 1. [PubMed: 7704582]

Pedersen PL, Hullihen J. Adenosine triphosphatase of rat liver mitochondria. Capacity of the homogeneous F1 component of the enzyme to restore ATP synthesis in urea-treated membranes. J Biol Chem. 1978; 253:2176-2183. published online EpubApr 10. [PubMed: 147273]

Petronilli V, Szabo I, Zoratti M. The inner mitochondrial membrane contains ion-conducting channels similar to those found in bacteria. FEBS Lett. 1989; 259:137-143. [PubMed: 2480918]

Petronilli V, Miotto G, Canton M, Brini M, Colonna R, Bernardi P, Di Lisa F. Transient and longlasting openings of the mitochondrial permeability transition pore can be monitored directly in intact cells by changes in mitochondrial calcein fluorescence. Biophys J. 1999; 76:725-734. DOI: 10.1016/S0006-3495(99)77239-5 [PubMed: 9929477]

Pogoryelov D, Reichen C, Klyszejko AL, Brunisholz R, Muller DJ, Dimroth P, Meier T. The oligomeric state of $\mathrm{c}$ rings from cyanobacterial F-ATP synthases varies from 13 to 15 . J Bacteriol. 2007; 189:5895-5902. DOI: 10.1128/JB.00581-07 [PubMed: 17545285]

Rizzuto R, Pozzan T. Microdomains of intracellular Ca2+: molecular determinants and functional consequences. Physiol Rev. 2006; 86:369-408. DOI: 10.1152/physrev.00004.2005 [PubMed: $16371601]$

Rizzuto R, Bernardi P, Pozzan T. Mitochondria as all-round players of the calcium game. J Physiol. 2000; 529(Pt 1):37-47. published online EpubNov 15. [PubMed: 11080249]

Rizzuto R, Marchi S, Bonora M, Aguiari P, Bononi A, De Stefani D, Giorgi C, Leo S, Rimessi A, Siviero R, Zecchini E, Pinton P. Ca(2+) transfer from the ER to mitochondria: when, how and why. Biochim Biophys Acta. 2009; 1787:1342-1351. published online EpubNov. [PubMed: 19341702]

Rizzuto R, De Stefani D, Raffaello A, Mammucari C. Mitochondria as sensors and regulators of calcium signalling. Nat Rev Mol Cell Biol. 2012; 13:566-578. DOI: 10.1038/nrm3412 [PubMed: 22850819]

Roestenberg P, Manjeri GR, Valsecchi F, Smeitink JA, Willems PH, Koopman WJ. Pharmacological targeting of mitochondrial complex I deficiency: the cellular level and beyond. Mitochondrion. 2012; 12:57-65. DOI: 10.1016/j.mito.2011.06.011 [PubMed: 21757032]

Schneggenburger R, Neher E. Presynaptic calcium and control of vesicle fusion. Curr Opin Neurobiol. 2005; 15:266-274. DOI: 10.1016/j.conb.2005.05.006 [PubMed: 15919191] 
Seidlmayer LK, Blatter LA, Pavlov E, Dedkova EN. Inorganic polyphosphate-an unusual suspect of the mitochondrial permeability transition mystery. Channels. 2012; 6:463-467. DOI: 10.4161/ chan.21939 [PubMed: 22990682]

Sorgato MC, Keller BU, Stuhmer W. Patch-clamping of the inner mitochondrial membrane reveals a voltage-dependent ion channel. Nature. 1987; 330:498-500. [PubMed: 2446143]

Stotz SC, Scott LO, Drummond-Main C, Avchalumov Y, Girotto F, Davidsen J, Gomez-Garcia MR, Rho JM, Pavlov EV, Colicos MA. Inorganic polyphosphate regulates neuronal excitability through modulation of voltage-gated channels. Mol brain. 2014; 7:42.doi: 10.1186/1756-6606-7-42 [PubMed: 24886461]

Szabo I, Zoratti M. The giant channel of the inner mitochondrial membrane is inhibited by cyclosporin A. J Biol Chem. 1991; 266:3376-3379. [PubMed: 1847371]

Szabo I, Bernardi P, Zoratti M. Modulation of the mitochondrial megachannel by divalent cations and protons. J Biol Chem. 1992; 267:2940-2946. [PubMed: 1371109]

Tang Y, Zucker RS. Mitochondrial involvement in post-tetanic potentiation of synaptic transmission. Neuron. 1997; 18:483-491. [PubMed: 9115741]

Tang HL, Tang HM, Fung MC, Hardwick JM. In vivo CaspaseTracker biosensor system for detecting anastasis and non-apoptotic caspase activity. Sci Report. 2015; 5:9015.doi: 10.1038/srep09015

Vander Heiden MG, Chandel NS, Li XX, Schumacker PT, Colombini M, Thompson CB. Outer mitochondrial membrane permeability can regulate coupled respiration and cell survival. Proc Natl Acad Sci U S A. 2000; 97:4666-4671. [PubMed: 10781072]

Vander Heiden MG, Li XX, Gottleib E, Hill RB, Thompson CB, Colombini M. Bcl-xL promotes the open configuration of the voltage-dependent anion channel and metabolite passage through the outer mitochondrial membrane. J Biol Chem. 2001; 276:19414-19419. [PubMed: 11259441]

Walker JE. The ATP synthase: the understood, the uncertain and the unknown. Biochem Soc Trans. 2013; 41:1-16. DOI: 10.1042/BST20110773 [PubMed: 23356252]

Wang W, Fang H, Groom L, Cheng A, Zhang W, Liu J, Wang X, Li K, Han P, Zheng M, Yin J, Mattson MP, Kao JP, Lakatta EG, Sheu SS, Ouyang K, Chen J, Dirksen RT, Cheng H. Superoxide flashes in single mitochondria. Cell. 2008; 134:279-290. DOI: 10.1016/j.cell. 2008.06.017 [PubMed: 18662543]

Wittig I, Schagger H. Supramolecular organization of ATP synthase and respiratory chain in mitochondrial membranes. Biochim Biophys Acta. 2009; 1787:672-680. DOI: 10.1016/j.bbabio. 2008.12.016 [PubMed: 19168025]

Woodfield K, Ruck A, Brdiczka D, Halestrap AP. Direct demonstration of a specific interaction between cyclophilin-D and the adenine nucleotide translocase confirms their role in the mitochondrial permeability transition. Biochem J. 1998; 336(Pt 2):287-290. published online EpubDec 1. [PubMed: 9820802]

Youle RJ, Strasser A. The BCL-2 protein family: opposing activities that mediate cell death. Nat Rev Mol Cell Biol. 2008; 9:47-59. [PubMed: 18097445]

Zakharov SD, Li X, Red'ko TP, Dilley RA. Calcium binding to the subunit c of E. coli ATP-synthase and possible functional implications in energy coupling. J Bioenerg Biomembr. 1996; 28:483494. published online EpubDec. [PubMed: 8953380]

Zucker RS, Regehr WG. Short-term synaptic plasticity. Annu Rev Physiol. 2002; 64:355-405. [PubMed: 11826273] 

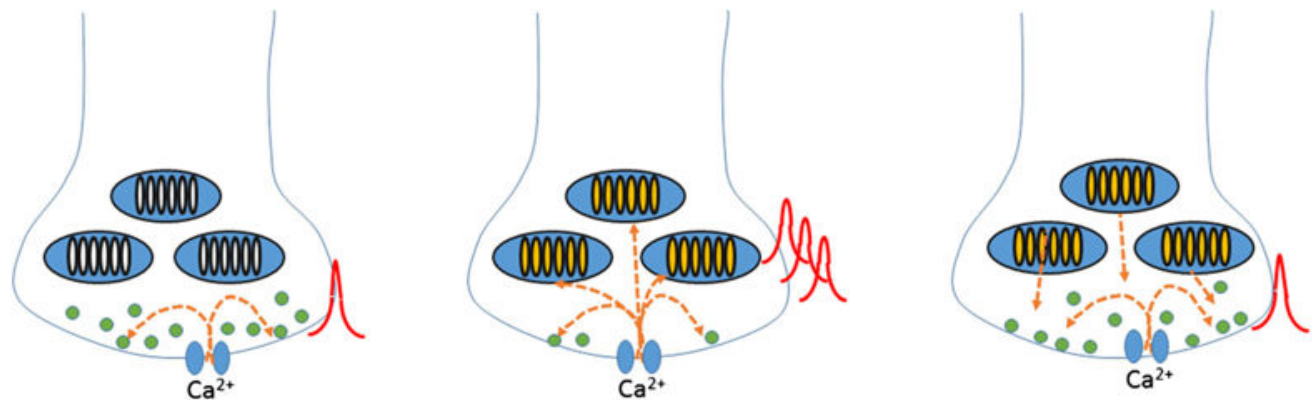

1. An action potential invades the terminal. 2. Repeated action potentials (tetanus) invade terminal. Some vesicles fuse, releasing neurotransmitter. Many vesicles fuse.

3. Calcium is released from mitochondria. When another action potential invades the terminal, the increased calcium levels from mitochondrial release plus plasma membrane $\mathrm{Ca}^{2 *}$ influx increase vesicle fusion, potentiating neurotransmission.

Fig. 1.

Mitochondrial $\mathrm{Ca}^{2+}$ buffering contributes to post-tetanic potentiation of neurotransmitter release. Images left to right show how $\mathrm{Ca}^{2+}$ uptake by and re-release from mitochondria enhance synaptic vesicle fusion and thereby increase neurotransmission 


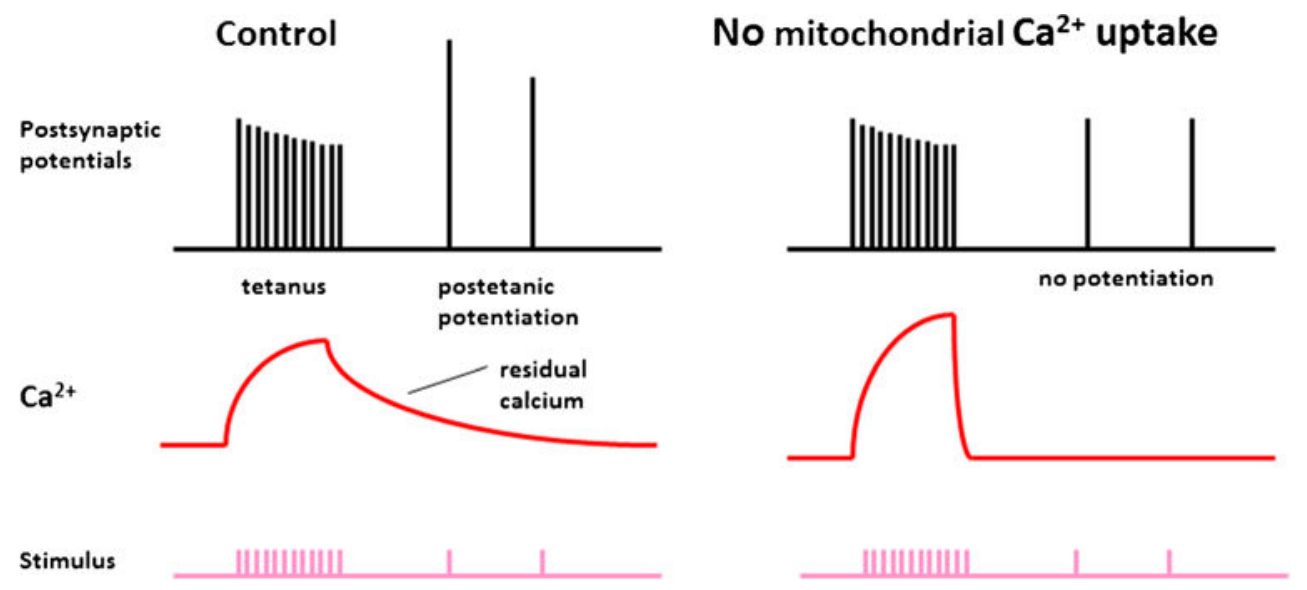

Fig. 2.

Mitochondrial $\mathrm{Ca}^{2+}$ is necessary for short term synaptic plasticity. Left panel demonstrates that mitochondrial $\mathrm{Ca}^{2+}$ contributes to the $\mathrm{Ca}^{2+}$ remaining in the synapse for about $1 \mathrm{~min}$ after a tetanus. After a tetanus, postsynaptic potentials initiated by neurotransmitter release are potentiated briefly. The right panel demonstrates that residual $\mathrm{Ca}^{2+}$ is necessary for these short term increases in neurotransmission. Both residual $\mathrm{Ca}^{2+}$ and posttetanic potentiation are dependent on mitochondrial $\mathrm{Ca}^{2+}$ release and are prevented by elimination of mitochondrial $\mathrm{Ca}^{2+}$ handling 


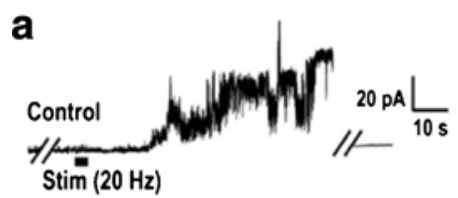

b

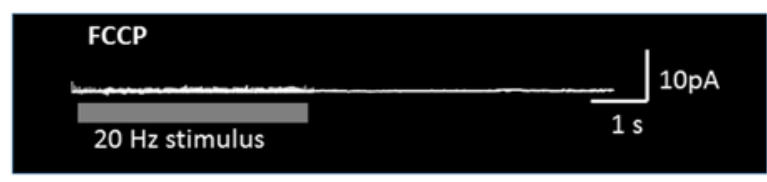

$\mathbf{C}$

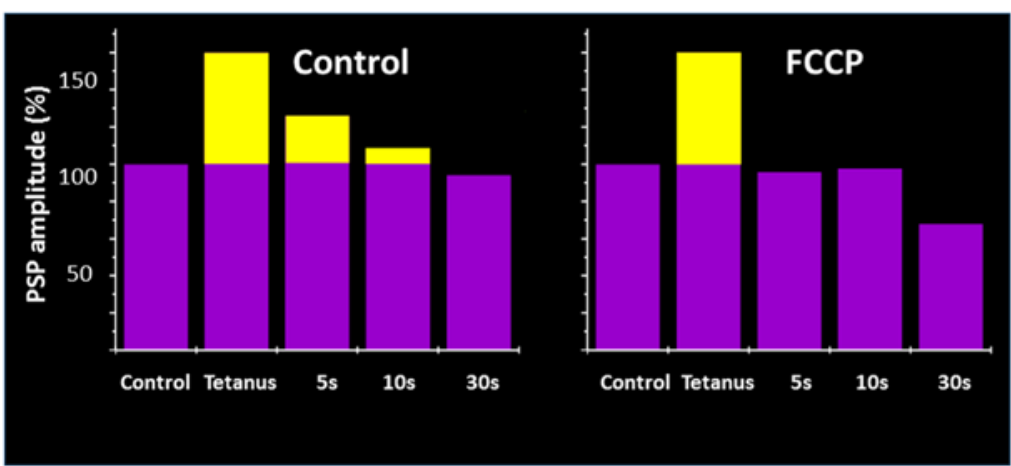

Fig. 3.

Mitochondrial channel activity is necessary for short term plasticity. a Mitochondrial membrane recording obtained during and after brief high frequency stimulation (tetanus) given to the presynaptic nerve. Stimulation leads to delayed increases in mitochondrial membrane conductance that outlast the tetanus for up to $1 \mathrm{~min}$. b Mitochondrial membrane recording obtained during and after brief high frequency stimulation (tetanus) given to the presynaptic nerve in the presence of the mitochondrial protonophore FCCP. FCCP prevents the change in mitochondrial membrane conductance after a tetanus. c FCCP prevents short term posttetanic potentiation of neurotransmitter release 

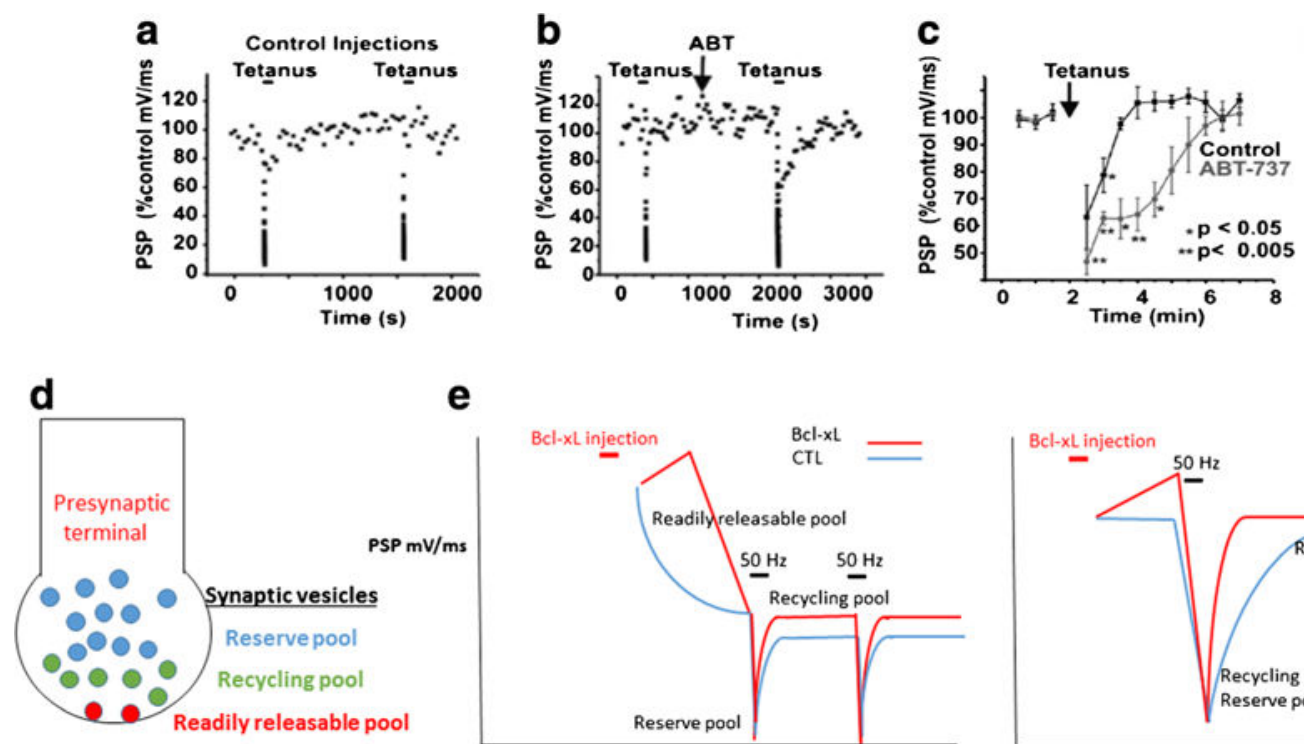

e
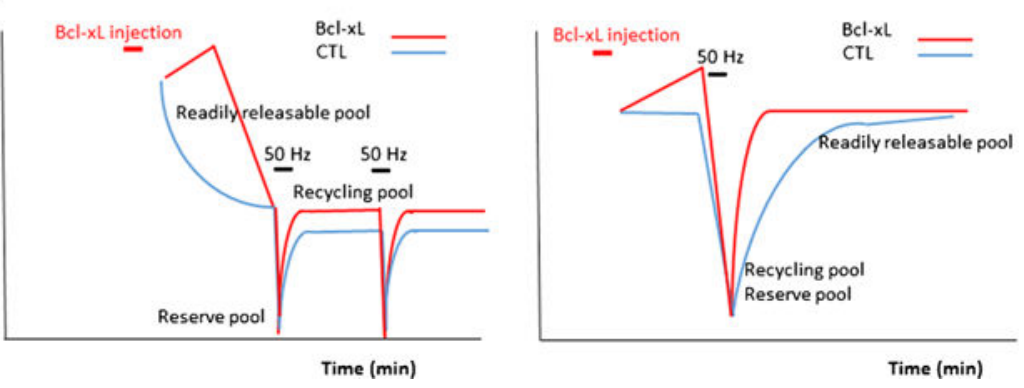

Fig. 4.

Recovery of the readily releasable pool of neurotransmitter is regulated by $\mathrm{Bcl}-\mathrm{x}_{\mathrm{L}}$. a Change in postsynaptic potential (PSP) amplitude over time in recordings from synapses undergoing repeated tetani. During the tetanus, depression of PSP amplitude occurs followed by rapid recovery in PSP amplitude after the tetanus. b, $\mathbf{c}$ Recovery time of PSP amplitude is prolonged by the Bcl- $\mathrm{x}_{\mathrm{L}}$ inhibitor ABT-737, preventing recovery of the readily releasable pool of synaptic vesicles. d Diagram demonstrating three different synaptic vesicle pools. The readily releasable pool is defined as those vesicles that are docked at the presynaptic membrane and ready for release. Recovery of docked vesicles takes time and is dependent on $\mathrm{Ca}^{2+}$ and the $\mathrm{Ca}^{2+}$ binding protein calmodulin. e (left panel) During frequent stimulation at $2 \mathrm{~Hz}$, there is no time for recovery of the readily releasable pool. Bcl- $x_{\mathrm{L}}$ injection into the presynaptic terminal does not influence recovery to the recycling pool that is releasing neurotransmitter at this frequency. (right panel) $\mathrm{Bcl}-\mathrm{x}_{\mathrm{L}}$ enhances the rate of recovery to the readily releasable pool that most slowly recovers after a tetanus. Therefore $\mathrm{Bcl}-\mathrm{x}_{\mathrm{L}}$ enhances the rate of recovery of this slowly recovering vesicle pool during stimulation at $0.03 \mathrm{~Hz}$ 
a

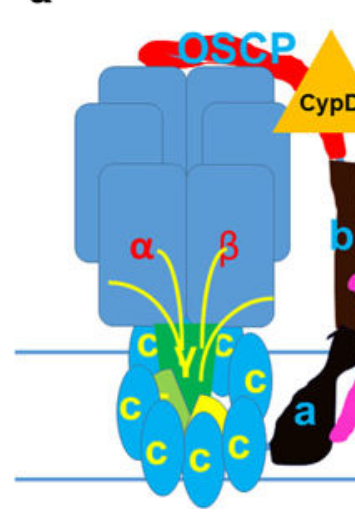

b

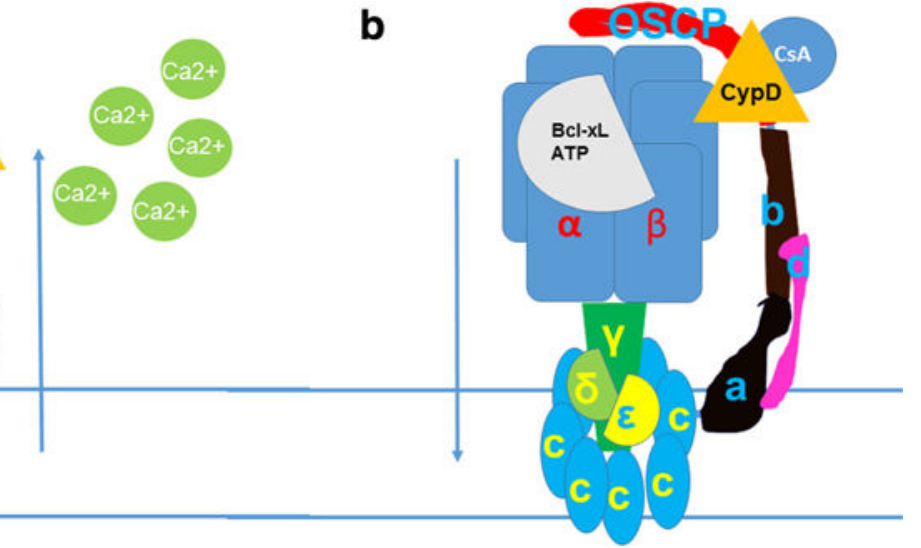

Fig. 5.

The c-subunit of the ATP synthase forms the mPTP. a The c-subunit ring expands and the $\mathrm{F}_{1}$ lifts away from the mouth of the pore when $\mathrm{Ca}^{2+}$ interacts with $\mathrm{F}_{1}$. b Bcl- $\mathrm{x}_{\mathrm{L}}$ or ATP/ADP binding to the $\beta$ subunit or CsA interacting with CypD on OSCP prevent $F_{1}$ removal from the mouth of the mPT pore. These mPTP inhibitors also decrease c-subunit ring diameter and channel conductance. The relative closure of the leak channel within the c-subunit ring provides enhanced coupling to the inner membrane, improving the efficiency of ATP production by the ATP synthase 